\title{
Pengaruh biaya saluran distribusi terhadap volume penjualan
}

\author{
Dedeh* Rita Meila Lestari** \\ *Universitas Galuh dedeh.akt15@gmail.com, Ciamis, Indonesia \\ **Universitas Galuh, Rita.ml@gmail.com Ciamis, Indonesia
}

\section{ARTICLE INFO}

Article history:

Received 09 Maret 2018

Received I Revised 26 Juli

2018

Accepted 31 Juli 2018

Keywords:

Channel Cost

Distribution, Sales

Volume.

\begin{abstract}
A B S T RA C T
The purpose of this study to analyzing description and influence of disitribution cost to sales volume in PD Azkia Snack. This research use descriptive and regressive method to analyzing influence of distribution cost to sales volume. Data collection techniques in this study are observation, interviews and documentation. Based on the results of the research are known: 1) The cost of distribution channel in PD Azkia Snack Ciamis from 2012 - 2016 has increased, 2) Sales volume in PD Azkia Snack Ciamis from 2012 - 2016 has increased, but the percentage of change fluctuate, 3) which is positive with a very strong relationship between distribution channel cost to sales volume on PD Azkia Snack Ciamis, with coefficient value of corelai (rx1y) equal to 0,99 , coefficient of determination value (KD) equal to $98,80 \%$, and simple linear regression equation is $Y=112.83+7.03 X$ with the number of tcount 15.74 and ttable 3.18. The conclusion from this research is positive relationship between distribution channel cost to sales volume.

Tujuan penelitian ini untuk menganalisis deskripsi dan pengaruh biaya disitribusi terhadap volume penjualan pada PD Azkia Snack. Penelitian ini menggunakan metode deskriptif dan regresi untuk menganalisis pengaruh biaya distribusi terhadap volume penjualan. Teknik pengumpulan data dalam penelitian ini adalah observasi, wawancara dan dokumentasi. Berdasarkan hasil penelitian diketahui: 1) Biaya saluran distribusi di PD Azkia Snack Ciamis dari tahun 2012 - 2016 mengalami peningkatan, 2) Volume penjualan di PD Azkia Snack Ciamis dari tahun 2012 - 2016 mengalami peningkatan, tetapi persentase perubahan fluktuatif, 3) yang positif dengan hubungan yang sangat kuat antara biaya saluran distribusi terhadap volume penjualan pada PD Azkia Snack Ciamis, dengan nilai koefisien korelasi ( $\left.\mathbf{r x}_{1} \mathbf{y}\right)$ sebesar 0,99, nilai koefisien determinasi (KD) sebesar 98, 80\%, dan persamaan regresi linier sederhana adalah $Y=112,83+7,03 X$ dengan jumlah tcount 15,74 dan ttabel 3,18. Kesimpulan dari penelitian ini adalah hubungan positif antara biaya saluran distribusi terhadap volume penjualan
\end{abstract}

AKUISISI : Jurnal Akuntansi

Website : http://www.fe.ummetro.ac.id/ejournal/index.php/JA

This is an open access article distributed under the terms of the Creative Commons Attribution 4.0 International License, which permits unrestricted use, distribution, and reproduction in any medium, provided the original work is properly cited.

E-mail address: dedeh.akt15@gmail.com,

Peer review under responsibility of Akuisisi : Accounting Journal. 2477-2984.

http://dx.doi.org/10.24217 
Perkembangan perusahaan dan laba yang dicapai perusahaan dapat digunakan sebagai alat ukur terhadap keberhasilan perusahaan dalam menjalankan aktivitas yang berkenaan dengan operasinya. Jika tujuan perusahaan tercapai maka kelangsungan hidup perusahaan dimasa yang akan datang tetap mampu dipertahankan dan mampu bersaing dengan perusahaan lain karena dapat meningkatkan volume penjualan setiap tahunnya.

Volume penjualan adalah produk yang terjual pada kurun waku tertentu karena adanya kegiatan pemasaran yang dilakukan (Salindeho \& Triyonowati, 2014). Salah satu faktor yang mempengaruhi volume penjualan diantaranya biaya saluran distribusi. Saluran distribusi adalah serangkaian lembaga yang melakukan semua kegiatan yang digunakan untuk menyalurkan produk dan status pemilikannya dari produsen ke konsumen akhir atau pemakai bisnis (Sunyoto, 2014). Penelitian yang dilakukan oleh Munawar \& Marpaung (2008) yang dilakukan di PT. Winner Garment membuktikan bahwa adanya saluran distribusi ini adalah memperlancar dan mempermudah penyampaian barang dari produsen ke konsumen sehingga mampu meningkatkan tingkat kepuasan konsumen yang mampu meningkatkan volume penjualan.

PD. Azkia Snack Ciamis merupakan salah satu perusahaan manufaktur yang bergerak di bidang pembuatan makanan ringan, yaitu baso goreng atau lebih dikenal dengan istilah basreng. Dalam kegiatan usahanya PD. Azkia Snack telah menjangkau agen-agen besar maupun toko-toko kecil di wilayah Ciamis, Tasikmalaya, Banjar, Cirebon, Sumedang, Cilacap, Bandung, Jakarta. Semenjak tahun 2012 hingga tahun 2016 PD. Azkia Snack selalu meningkatkan biaya saluran distribusi namun peningkatan biaya tersebut tidak selaras dengan kenaikan volume penjualan, yaitu presentase perubahan volume penjualan pada PD. Azkia Snack tidak stabil, yang sifatnya (fluktuatif)

Berdasarkan fenomena biaya distribusi dan volume penjualan yang terjadi pada PD Azkia Snack serta ketidakkonsistenan dengan konsep dan hasil pada penelitian sebelumnya, maka penelitian ini bertujuan untuk menggambarkan aliran biaya distribusi dan volume penjualan lalu membuktikan pengaruh hubungan antara biaya saluran distribusi dengan tingkat volume.

\section{METODE}

Penelitian dilaksanakan di PD. Azkia Snack Ciamis. Objek dalam penelitian ini yaitu, biaya saluran distribusi dan volume penjualan pada PD. Azkia Snack Ciamis. Untuk menjawab masalah yang ada dalam penelitian, penelitian ini menggunakan metode analisis penelitian deskriptif dan pengujian pengaruh.

Adapun variabel yang diteliti meliputi biaya saluran distribusi dengan indikator biaya transportasi dan biaya distributor yang berpengaruh terhadap volume penjualan selama lima tahun yaitu tahun 2012 - 2016. Untuk mendapatkan data-data informasi yang diperlukan sebagai sumber yang menunjang, penulis mengumpulkan data melalui prosess yang dijelaskan pada gambar satu (1) di bawah ini. 


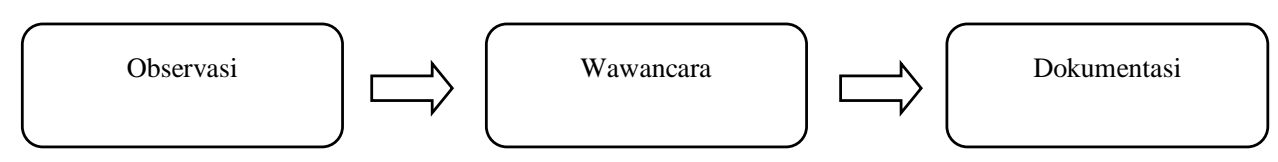

Gambar 1.

Proses Pengumpulan Data

Langkah pertama pengumpulan data dalam penelitian ini adalah observasi yang dilkukan dengan pengamatan langsung baik berupa tulisan-tulisan dan dokumen-dokumen yang berkaitan dengan pengaruh biaya saluran distribusi terhadap peningkatan volume penjualan pada PD. Azkia Snack Ciamis. Setelah dilakukan pengamatan langkah berikutnya ialah dengan melakukan tanya jawab langsung dengan pihak manajemen PD. Azkia Snack yang berkompeten untuk memperoleh penjelasan-penjelasan yang diperlukan dengan masalah yang diteliti. Langkah terakhir yaitu penulis mengumpulkan data primer yang diperoleh secara langsung dari PD. Azkia Snack Ciamis tahun 2012-2016. Setelah data terkumpul langkah terakhir dalam penelitian yaitu melakukan analisis. Analisis yang digunakan dalam penelitian adalah analisis deskriptif dan analisis regresi linier.

\section{HASIL DAN PEMBAHASAN}

\subsection{Hasil Penelitian}

Bagian ini menjelaskan hasil penelitian yang telah dilakukan. Hasil penelitian tersebut meliputi; deskripsi biaya saluran distribusi, deskripsi volume penjualan dan analisis pengaruh saluran biaya distribusi terhadap volume penjualan.

\subsection{Deskripsi Biaya Saluran Distribusi}

a. Biaya Transportasi

Biaya transportasi PD. Azkia Snack Ciamis mengalami kenaikan setiap tahunnya, hal ini disebabkan karena Bahan Bakar Minyak (BBM) selalu mengalami kenaikan. Berikut ini presentase kenaikan biaya transportasi PD. Azkia Snack Ciamis dari tahun 2012-2016:

$$
\begin{aligned}
& 2012-2013=\frac{11.860 .000-11.350 .000}{11.350 .000} \times 100=4,49 \% \\
& 2013-2014=\frac{12.520 .000-11.860 .000}{11.860 .000} \times 100=5,56 \% \\
& 2014-2015=\frac{13.690 .000-12.520 .000}{12.520 .000} \times 100=9,34 \% \\
& 2015-2016=\frac{15.500 .000-13.690 .000}{13.690 .000} \times 100=13,22 \%
\end{aligned}
$$


Biaya Distributor

Berikut ini presentase kenaikan biaya distributor PD. Azkia Snack Ciamis dari tahun 2012-2016:

$$
\begin{aligned}
& 2012-2013=\frac{17.500 .000-16.800 .000}{16.800 .000} \times 100=4,16 \% \\
& 2013-2014=\frac{18.600 .000-17.500 .000}{17.500 .000} \times 100=6,28 \% \\
& 2014-2015=\frac{20.400 .000-18.600 .000}{18.600 .000} \times 100=9,68 \% \\
& 2015-2016=\frac{23.200 .000-20.400 .000}{20.400 .000} \times 100=13,72 \%
\end{aligned}
$$

Berdasarkan data biaya transportasi dan biaya distributor diatas yang selalu mengalami peningkatan setiap tahunnya begitu pula dengan presentase perubahan yang ikut mengalami kenaikan, maka presentase perubahan biaya saluran distribusi setiap tahunnya juga mengalami peningkatan. Berikut ini presentase kenaikan biaya saluran distribusi dari tahun 20102 - 2016 di PD. Azkia Snack Ciamis:

$$
\begin{aligned}
& 2012-2013=\frac{29.360 .000-28.150 .000}{28.150 .000} \times 100=4,30 \% \\
& 2013-2014=\frac{31.120 .000-29.360 .000}{29.360 .000} \times 100=6,00 \% \\
& 2014-2015=\frac{34.090 .000-31.120 .000}{31.120 .000} \times 100=9,54 \% \\
& 2015-2016=\frac{38.700 .000-34.090 .000}{34.090 .000} \times 100=13,52 \%
\end{aligned}
$$


Berdasarkan uraian di atas, maka peneliti dapat jelaskan data biaya saluran distribusi pada PD. Azkia Snack Ciamis dengan menggunakan tabel sebagai berikut:

\section{Tabel 1}

Biaya Saluran Distribusi PD. Azkia Snack CiamisTahun 2012-2016

\begin{tabular}{cccccc}
\hline NO & Tahun & $\begin{array}{c}\text { Biaya } \\
\text { Transportasi } \\
(\mathrm{Rp})\end{array}$ & $\begin{array}{c}\text { Biaya Distributor } \\
(\mathrm{Rp})\end{array}$ & $\begin{array}{c}\text { Biaya Saluran } \\
\text { Distribusi } \\
(\mathrm{Rp} .)\end{array}$ & $\%$ \\
\hline 1 & 2011 & 11.350 .000 & 16.800 .000 & 28.150 .000 & - \\
2 & 2012 & 11.860 .000 & 17.500 .000 & 29.360 .000 & 4,30 \\
3 & 2013 & 12.520 .000 & 18.600 .000 & 31.120 .000 & 6,00 \\
4 & 2014 & 13.690 .000 & 20.400 .000 & 34.090 .000 & 9,54 \\
5 & 2015 & 15.500 .000 & 23.200 .000 & 38.700 .000 & 13,52 \\
& Total & 64.920 .000 & 96.500 .000 & 161.420 .000 & \\
& Rata-rata & 12.984 .000 & 19.300 .000 & 32.284 .000 & \\
\hline
\end{tabular}

Sumber: PD. Azkia Snack Ciamis (2017)

Berdasarkan tabel satu (1) di atas, menunjukkan bahwa biaya saluran distribusi pada PD. Azkia Snack dari tahun 2012-2016 selalu mengalami peningkatan, begitu juga hal nya dengan presentase perubahan biaya saluran distribusi selalu mengalami peningkatan pula setiap tahunnya. Biaya saluran distribusi yang diperoleh PD Azkia Snack pada tahun 2012 sebesar Rp. 28.150.000. Pada tahun 2013 mengalami kenaikan 4,30\% sehingga biaya saluran distrbusi yang diperoleh perusahaan sebesar Rp. 29.360.000. Pada tahun 2014 mengalami kenaikan 6,00\% sehingga biaya saluran distrbusi yang diperoleh perusahaan sebesar Rp. 31.120.000. Pada tahun 2015 mengalami kenaikan 9,54\% sehingga biaya saluran distrbusi yang diperoleh perusahaan sebesar Rp. 34.090.000. Pada tahun 2016 mengalami kenaikan 13,52\% sehingga biaya saluran distrbusi yang diperoleh perusahaan sebesar Rp. 38.700.000. Biaya saluran distrbusi PD. Azkia Snack Ciamis yang paling tinggi terjadi pada tahun 2016 yaitu sebesar Rp. 38.700.000, dengan presentase kenaikan dari tahun sebelumnya sebesar 13,52\%. Jumlah biaya saluran distribusi PD. Azkia Snack dari tahun 2012-2016 sebesar Rp. 161.420.000dengan rata-rata biaya saluran distribusi sebesar Rp. 32.284.000 setiap tahunnya.

Saluran distribusi sangat menentukan perusahaan untuk dapat mendistribusikan produk sampai ketangan konsumen sehingga dapat memperoleh laba yang maksimum. Didalam saluran distribusi, produsen seringkali menggunakan perantara sebagai penyalurnya, dimana perantara ini merupakan suatu kegiatan yang berdiri sendiri yang berada diantara produsen dan konsumen akhir. Hal ini sesuai dengan pendapat Etzel (dalam Sunyoto, 2014:172) bahwa "Kegiatan distribusi merupakan kegiatan yang terdiri dari berbagai kegiatan pemasaran yang berusaha memperlancar dan mempermudah penyampaian barang dari produsen untuk sampai ke tangan konsumen”.

Berdasarkan hasil penelitian, biaya saluran distribusi di PD. Azkia Snack Ciamis selama lima tahun terakhir, mulai dari tahun 2012 - 2016 selalu mengalami peningkatan, begitu juga dengan presentase perubahan biaya saluran distribusi setiap tahunnya mengalami peningkatan pula. Peningkatan biaya saluran distribusi PD. Azkia Snack Ciamis ini dilakukan guna menghadapi persaingan yang semakin ketat, sehingga PD. Azkia Snack Ciamis dituntut untuk dapat lebih jeli dalam kegiatan pemasaran terutama dalam kegiatan distribusi, agar dapat memperbaiki kualitas saluran distribusi secara terus menerus sehingga memberikan kepuasan kepada konsumen. Selain itu PD. Azkia Snack Ciamis juga selalu berusaha untuk selalu memperluas wiayah pemasarannya agar dapat meningkatkan volume penjualan. 
Saluran distribusi yang dijalankan PD. Azkia Snack Ciamis yang tepat dan dapat memberikan kemudahan konsumen dalam mendapatkan suatu produk sangat mempengaruhi terhadap minat beli dari konsumen yang pada akhirnya akan meningkatkan volume penjualan. Volume penjualan akan suatu produk dipengaruhi oleh kegiatan distribusi yang dilakukan. Hal ini karena distribusi mempengaruhi kondisi psikologis konsumen, yang akhirnya akan berkesimpulan kebutuhan dan kemudahan akses untuk membeli produk yang ditawarkan. Dengan ditingkatkannya biaya saluran distribusi perusahaan maka volume penjulan juga akan semakin meningkat.

\subsection{Deskripsi Volume Penjualan pada PD. Azkia Snack Ciamis}

Adapun volume penjualan yang diperoleh selama periode 2012-2016 adalah sebagai berikut:

Volume penjualan tahun $2012=$ Harga $\mathrm{X}$ Jumlah barang

$=$ Rp. 22.500 X 13.716

$=$ Rp. 308.610 .000

Jadi volume penjualan yang dihasilkan pada tahun 2012 senilai Rp. 308.610.000.

Volume penjualan tahun $2013=$ Harga X Jumlah barang

$=$ Rp. $23.000 \times 13.815$

$=$ Rp. 317.745.000

Jadi volume penjualan yang dihasilkan pada tahun 2013 senilai Rp. 317.745.000.

Volume penjualan tahun $2014=$ Harga X Jumlah barang

$=$ Rp. 24.000 X 13.980

$=$ Rp. 335.520 .000

Jadi volume penjualan yang dihasilkan pada tahun 2014 senilai Rp. Rp. 335.520.000.

Volume penjualan tahun $2015=$ Harga X Jumlah barang

$=$ Rp. 24.500 X 14.227

$=$ Rp. 348.561 .500

Jadi volume penjualan yang dihasilkan pada tahun 2015 senilai Rp. 348.561.500.

Volume penjualan tahun $2016=$ Harga X Jumlah barang

$=$ Rp. $25.000 \times 15.245$

$=$ Rp. 381.125.000

Jadi volume penjualan yang dihasilkan pada tahun 2016 senilai Rp. 381.125.000.

Berdasarkan volume penjualan di atas, maka peneliti dapat uraikan data perubahan volume penjualan PD. Azkia Snack Ciamis dari tahun 2012-2016 sebagai berikut:

$$
\begin{aligned}
& 2012-2013=\frac{317.745 .000-308.610 .000}{308.610 .000} \times 100=2,96 \% \\
& 2013-2014=\frac{335.520 .000-317.745 .000}{317.745 .000} \times 100=5,59 \% \\
& 2014-2015=\frac{348.561 .500-335.520 .000}{335.520 .000} \times 100=3,89 \%
\end{aligned}
$$

$2015-2016=\frac{381.125 .000-348.561 .500}{348.561 .500} \times 100=9,34 \%$ 
Berdasarkan uraian di atas, maka peneliti dapat jelaskan data volume penjualan PD. Azkia Snack Ciamis dengan menggunakan tabel sebagai berikut:

Tabel 2

Volume Penjualan PD. Azkia Snack Ciamis

Tahun 2012-2016

\begin{tabular}{cccc}
\hline NO & Tahun & $\begin{array}{c}\text { Volume Penjualan } \\
(\text { Rp. })\end{array}$ & $\%$ \\
\hline 1 & 2012 & 308.610 .000 & - \\
2 & 2013 & 317.745 .000 & 2,96 \\
3 & 2014 & 335.520 .000 & 5,59 \\
4 & 2015 & 348.561 .500 & 3,89 \\
5 & 2016 & 381.125 .000 & 9,34 \\
& Total & 1.691 .561 .500 & \\
& Rata-rata & 338.312 .300 & \\
\hline
\end{tabular}

Sumber: PD. Azkia Snack Ciamis (2017)

Berdasarkan tabel dua (2) di atas, menunjukkan bahwa kurun waktu lima tahun volume penjualan selalu mengalami peningkatan, namun persentase perubahan volume penjualan PD. Azkia Snack Ciamis mengalami fluktuatif. Volume penjualan yang diperoleh PD Azkia Snack pada tahun 2012 sebesar Rp. 308.610.000. Pada tahun 2013 mengalami kenaikan 2,96\% sehingga volume penjualan yang diperoleh perusahaan sebesar Rp. 317.745.000. Pada tahun 2014 mengalami kenaikan 5,59 \% sehingga volume penjualan yang diperoleh perusahaan sebesar Rp. 335.520.000. Pada tahun 2015 mengalami kenaikan 3,89\% sehingga volume penjualan yang diperoleh perusahaan sebesar Rp. 348.561.000, meskipun presentase perubahan volume penjualan mengalami penurunan dibandingkan tahun sebelumnya. Pada tahun 2016 mengalami kenaikan 9,34\% sehingga volume penjualan yang diperoleh perusahaan sebesar Rp. 381.125.000. Volume penjualan PD. Azkia Snack Ciamis yang paling tinggi terjadi pada tahun 2016 yaitu sebesar Rp. 381.125.000, dengan presentase kenaikan dari tahun sebelumnya sebesar 9,34\%. Jumlah volume penjualan PD. Azkia Snack dari tahun 2012-2016 sebesar Rp. 1.691.561.500 dengan rata-rata volume penjualan sebesar Rp. 338.312.300setiap tahunnya.

Setiap perusahaan memiliki tujuan yang sama yaitu untuk memperoleh keuntungan atau laba yang optimal. Salah satu cara perusahaan untuk mencapai tujuan tersebut yaitu dengan meningkatkan terus volume penjualan dari produk yang dihasilkannya. Volume penjualan yang dicapai oleh PD. Azkia Snack Ciamis selama lima tahun terakhir, mulai dari tahun 2012 - 2016 selalu mengalami peningkatan, namun presentase kenaikannya mengalami fluktuatif atau tidak tetap, hal tersebut disebabkan oleh kegiatan pemasaran perusahaan. Hal ini sejalan dengan pendapat Swasta (Triyonowati, 2014:5) "Volume penjualan adalah banyak produk yang terjual pada kurun waktu tertentu karena adanya

kegiatan pemasaran yang dilakukan”. Kegiatan pemasaran yang dilakukan oleh PD. Azkia Snack Ciamis dalam upaya meningkatkan volume penjualan diantaranya yaitu dengan meningkatkan biaya saluran distribusi dan biaya kemasan setiap tahunnya. Namun dikarenakan adanya persaingan antar perusahaan, sehingga menyebabkan presentase perubahan volume penjualan dari tahun ke tahun mengalami fluktuatif.

Faktor lain yang mempengaruhi terhadap volume penjuaan diantaranya yaitu kondisi kemampuan perekonomian pasar, perubahan selera konsumen, jumlah modal yang digunakan 
perusahaan, promosi yang dilakukan perusahaan, harga jual satuan produk, dan lain-lain. Ketika volume pejualan perusahaan mengalami peningkatan maka akan berdampak pada keuntungan atau laba yang

diperoleh perusahaan. Hal ini sesuai dengan pendapat Swasta dan Irawan (Rimansyah, 2011:33) volume penjualan merupakan suatu studi mendalam tentang masalah penjualan bersih dari laporan rugi laba perusahaan. Jadi besar kecilnya laba yang diperoleh PD. Azkia Snack Ciamis dipengaruhi oleh kemampuan PD. Azkia Snack Ciamis tersebut dalam mencapai volume penjualan.

\subsection{Analisis Pengaruh Biaya Saluran Distribusi Terhadap Volume Penjualan pada PD. Azkia Snack Ciamis}

\section{a. Analisis Koefisien Korelasi}

Analisis koefisien korelasi digunakan untuk menentukan tingkat keeratan hubungan antara variabel $X_{1}$ (Biaya Saluran Distribusi) dengan variabel Y (Volume penjualan) pada PD. Azkia Snack Ciamis. Berdasarkan hasil perhitungan koefisien diperoleh nilai $r$ sebesar 0,994. Nilai koefisien korelasi tersebut berada pada rentang antara 0,80 - 1,000 dan termasuk ke dalam kategori sangat kuat (Sugiyono, 2013). Berdasarkan hasil ini dapat disimpulkan hubungan antara biaya saluran distribusi dengan volume penjualan pada PD.Azkia Snack Ciamis mempunyai hubungan yang sangat kuat.

\section{b. Analisis Koefisien Determinasi}

Koefisien determinasi yaitu untuk mengetahui berapa besar pengaruh variable independen dapat menjelasakn variabel dependen (Nazir, 2013). Berdasarkan hasil perhitungan diperoleh nilai koefisien determinasi sebesar 98,804\%. Hasil ini menjelaskan bahwa 98,804\% volume penjualan dapat dijelaskan oleh biaya saluran distribusi sedangkan sebesar 1,196\% dipengaruhi oleh faktor lain diluar variabel yang diteliti.

\section{c. Analisis Regresi Linear Sederhana}

Berdasarkan perhitungan analisis regresi linier diperoleh hasil persamaan perhitungan sebagai berikut:

$\hat{Y}=112,83+7,03 \mathrm{X}$

Regresi linier sederhana yang di peroleh adalah $\hat{Y}=112,83+7,03 X$

1) Nilai 112,83 merupakan nilai konstanta (a) artinya apabila tidak ada perubahan dari biaya saluran distribusimaka nilai volume penjualan adalah 112,83

2) Nilai 7,03 artinya biaya saluran distribusimemberikan pengaruh $1 \%$, apabila biaya saluran distribusinaik $1 \%$ maka nilai volume penjualan akan meningkat 7,03. Sedangkan apabila biaya saluran distribusiberkurang $1 \%$ maka nilai volume penjualan akan 
berkurang 7,03.Berdasarkan hasil perhitungan diperoleh hasil uji thitung sebesar 15,74 dengan $\mathrm{dk}=\mathrm{n}-2=5-2=3$ pada $\alpha=0,05$ maka $\mathrm{t}_{\text {tabel }}$ sebesar 3,18. Dengan demikian,

$\mathrm{t}_{\text {hitung }}$ sebesar 15,74 > $\mathrm{t}_{\text {tabel }}$ sebesar 3,18, hal ini menunjukkan bahwa terdapat pengaruh positif biaya saluran distribusi terhadap volume penjualan (Arikunto, 2010) .

Nilai 112,83 merupakan nilai konstanta (a) artinya apabila tidak ada perubahan dari biaya saluran distribusi maka nilai volume penjualan adalah 112,83 . Kemudian nilai 7,03 artinya biaya saluran distribusi memberikan pengaruh $1 \%$, apabila biaya saluran distribusi naik $1 \%$ maka nilai volume penjualan akan meningkat 7,03. Sedangkan apabila biaya saluran distribusiberkurang $1 \%$ maka nilai volume penjualan akan berkurang 7,03. Berdasarkan hasil uji hipotesis dapat diketahui dari hasil perhitungan $t_{\text {hitung }}$ sebesar 15,74 yang kemudian dibandingkan dengan $t_{\text {tabel }}$ 3,18 maka $t_{\text {hitung }} \geq t_{\text {tabel }}(15,74 \geq 3,18)$, hal ini menunjukkan bahwa terdapat pengaruh positif biaya saluran distribusi terhadap volume penjualan (Bungin, 2013)

Hal ini sejalan dengan penelitian terdahulu yang dilakukan oleh Salindeho \& Triyonowati (2014) saluran distribusi merupakan struktur unit lembaga atau organisasi yang sangat penting dan langsung berpengaruh terhadap perusahaan, yaitu sesuai dengan tujuan perusahaan meningkatkan volume penjualan yang mana memerlukan pengembangan dan perencanaan pemasaran agar dapat menjual dalam jumlah yang telah ditentukan sebelumnya."

\section{KESIMPULAN}

Berdasarkan hasil penelitian pada PD. Azkia Snack Ciamis maka diperoleh kesimpulan bahwa dengan meningkatan biaya distribusi channel akan berpengaruh terhadap peningkatan volume penjualan. Pengaruh peningkatan ini diakibatkan karena distribusi channel merupakan salah satu upaya perusahaan untuk meningkatkan kualitas pelayanan kepada konsumen dan memperluas pemasaran, semakin tinggi kepuasan konsumen dan pangsa pasar dapat meningkatkan tingkat volume penjualan dalam suatu perusahaan.

\section{DAFTAR PUSTAKA}

Arikunto, Suharsimi. 2010. Manajemen Penelitian. Jakarta: Rineka Cipta

Bungin, Burhan. 2013. Metodologi Penelitian Kuantitatif. Jakarta: Kencana Prenada Media Group

Nazir, Moh. 2013. Metode Penelitian. Bogor: Ghalia Indonesia

Sugiyono. 2013. Statistika untuk Penelitian. Bandung: Alfabeta

Sunyoto, Danang. 2014. Dasar-Dasar Manajemen Pemasaran (Konsep, Strategi dan Kasus). Yogyakarta: CAPS

Rimansyah. 2011. Pengaruh Biaya Promosi Terhadap Volume Penjualan Meubel pada PD. Jati Karya Palembang. Jurnal Media Wahana Ekonomika. (Vol. 8 No.2)

Munawar, A., \& Marpaung, B. S. (2008). Pengaruh Biaya Saluran Distribusi Terhadap Tingkat Volume Penjualan Pada PT. Winner Garment . Jurnal Ilmiah Kesatuan, 13 - 19. 
Salindeho, H. A., \& Triyonowati. (2014). Pengaruh Saluran Distribusi dan Harga Terhadap Peningkatan Volume Penjualan Pada PT. Fastrata Buana. Jurnal Ilmu \& Research Manajemen, 1 - 15.

Sunyoto, D. (2014). Dasar - Dasar Manajemen Pemasaran (Konsep, Strategi dan Kasus. Yogyakarta: CAPS. 